\title{
破砕帯地すべりにおける地下水位の挙動特性 \\ Characters of Groundwater Fluctuation in the Fractured Zone Type Landslides
}

\author{
近 藤 観 慈* 吉 松 弘 行* 吉 田 克 美* \\ Konji KoNDOH Hiroyuki YoshIMATSU Katsumi YoshIDA
}

\begin{abstract}
The authors proposed an estimation model of groundwater level which is able to be used when the basal groundwater level is already clarified and duration of precipitation is longer than $t_{1}$. This model definition is as follows:

$$
\gamma=(k \cdot i \cdot \beta / \ell) \cdot \Delta h+\alpha
$$

where $t_{1}$ is concentration time of groundwater from top of the catchment area to the observation point, $\gamma$ is the precipitation density, $k$ is coefficient of permeability, $i$ is hydraulic gradient, $\beta$ is effective porosity, $\ell$ is length of the catchment area, $\Delta h$ is groundwater ascent volume, $\alpha$ is invalid precipitation density.

Moreover, for the purpose of making to be sure the propriety of this model, we examined this model through the Taninouchi landslide, Kochi prefecture and Kuchisakamoto landslide, Shizuoka prefecture.

キーワード: 地下水位, 間隙水圧, 降雨, 水位上昇予測, 遅れ時間
\end{abstract}

\section{1.まえがき}

地すべりが豪雨や融雪時に多発することは周知の事実 であり, 地すべり地内の地下水位の上昇が, 地すべり土 塊の移動量を増加させることは, 多くの調査研究によっ て報告されている1)。すべり面での間隙水圧の上昇が斜 面の安定性を低下させることは, 斜面安定解析から理解 できることである。このことから, 地すべり地の地下水 の調査研究が多く実施されている。

しかしながら, 地すべり地の地下水の挙動は非常に複 雑で, 的確にその挙動を捉えることは難しい。その理由 として, 移動層内の䇢所によって透水性や地質特性が異 なっていること, 水みちの存在, あるいは間隙水圧の変 動をもたらす誘因の量とパターンの相違, さらに地すべ り活動に伴う水文定数の変化などが考えられる。このよ うなことから, 檜垣ら ${ }^{2)}$ は間隙水圧の挙動を考察し, 地す べり土塊の中間に難透水層の存在する場合には全孔スト レーナ方式の地下水位観測ではなく, すべり面での間隙 水圧を測定する必要があることを強調している。

ここでは，降雨による間隙水圧の変動を換算水位に置 き換え, 降雨によるすべり面での地下水位の上昇モデル を提案して, このモデルを谷の内地すべり及びロ坂本地 すべりに適用し，その妥当性を確認した。

\section{2. 解析モデルに用いた谷の内 ${ }^{3)}$ 及びロ坂本 ${ }^{4)}$ 地すべりの概要と間隙水圧計の設置状況}

\section{1 地すべり地の概要}

谷の内地すべりは高知市の西約 $23 \mathrm{~km}$ の仁淀川水系 谷屋敷川の上流部に位置する。地すべり地形を示す範囲 は斜面長 $1,100 \mathrm{~m}$, 幅 1,000 $\mathrm{m}$ に及んでいる（図一1）。 地すべり末端域の地質は, 秩父古生層の白木谷層群に属 する砂岩・粘板岩の互層からなり, 一部に苦鉄質凝灰岩・ チャート等を挟んでいる。これらの走向傾斜は $\mathrm{N} 60^{\circ} \mathrm{E}$ 〜 E-W, 約 $15^{\circ} \mathrm{S}$ で流れ盤構造を示している (図一)。

口坂本地すべり（図一3）は静岡県の大井川流域と安部

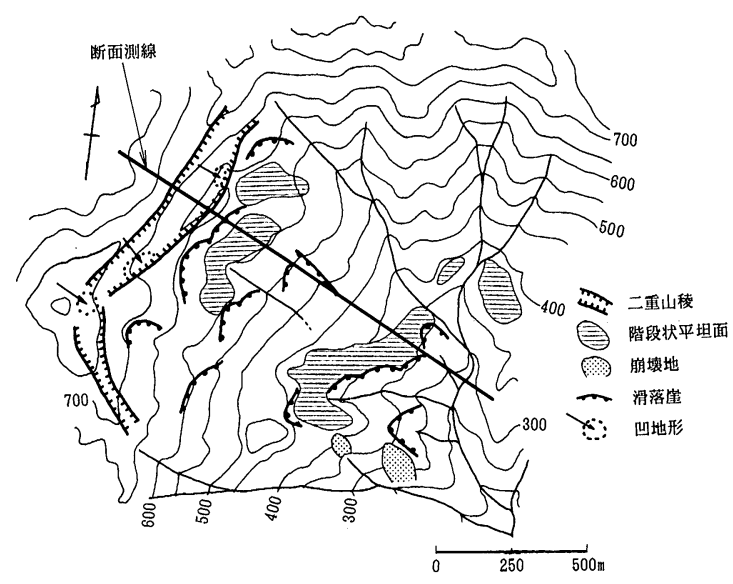

図-1 谷の内地すべりの地形 


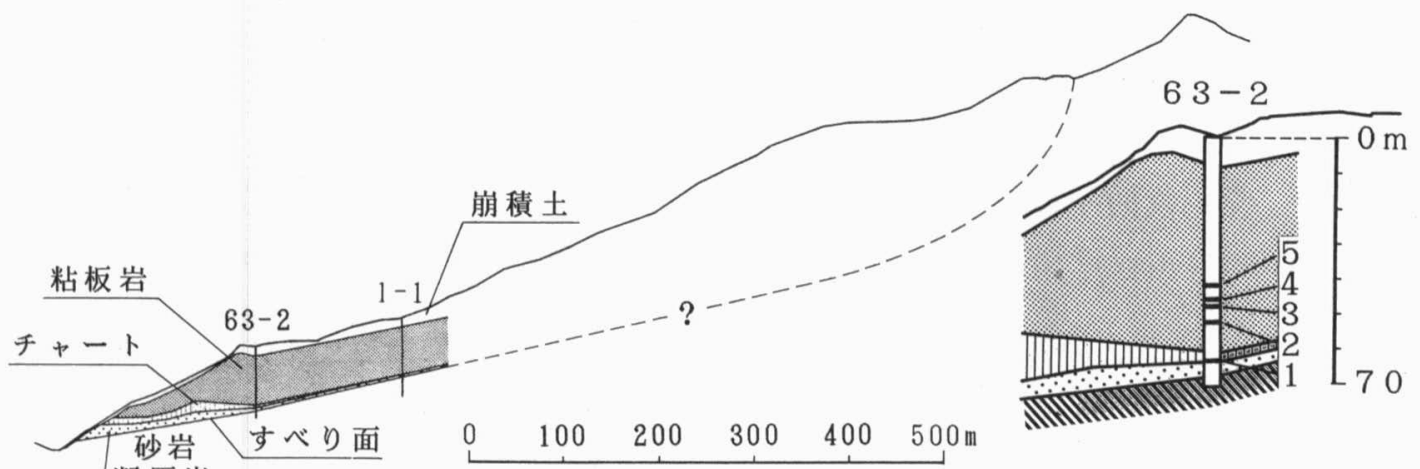

図ー2 谷の内地すべり断面図

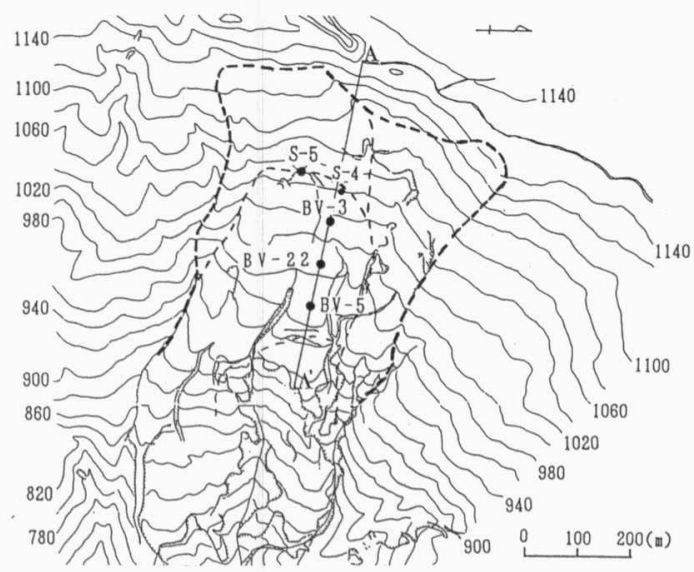

図ー3 口坂本地すべりの地形

川流域の分水嶺となっている尾根筋に接する安部川流域 側の斜面, 中河内川の源流部に位置する。地すべりの面 積は $2 \mathrm{~km}^{2}$ を超える大規模な地すべり地で, 地質は中生
代一古第三紀の著しく破砕された頁岩である（図一-4）。 全体に N 20 40ㅌ の走向を有している。

\section{2 間隙水圧計の設置状況}

谷の内地すべりの間隙水圧計は, 調査ボーリング孔 (BV-63-2) に異なる深度（地表面より $63.8 \mathrm{~m}, 52.8$ $\mathrm{m}, 48.3 \mathrm{~m}, 46.4 \mathrm{~m}, 42.3 \mathrm{~m})$ に設置され, 各間隙水压 計は 1 日 1 回の観測がなされている。この位置でのすべ り面深度は上方及び下方斜面の孔内傾斜計の観測により, 輝緑凝灰岩境界付近（深度 $64.0 \mathrm{~m}$ ) に推定されている。 間隙水圧計の設置方法は, 間隙水圧計設置位置を中心に $1.0 \mathrm{~m}$ の区間にフィルター材として砂を, それ以外の部 分にベントナイト, セメントミルクを用いて遮水し, 各 深度毎の間隙水圧を測定できるようになっている。この 中で, 最上段の深度 $42.3 \mathrm{~m}$ の間隙水圧計は地下水位よ り上位標高にあり, 変動データは得られていない。

口坂本地すべりの間隙水圧計は, 中央地すべりブロッ クの中央部 (BV-22) に設置されている。間隙水圧観測

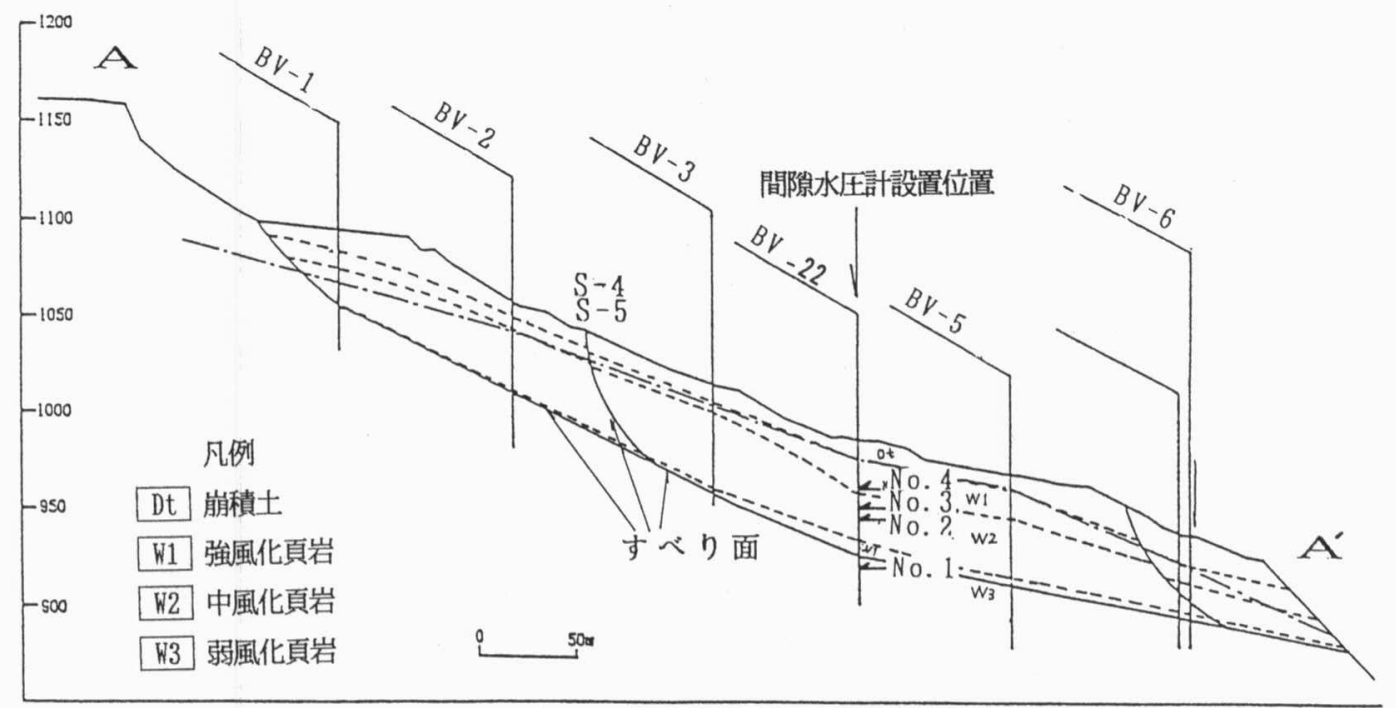

図ー4 口坂本地すべり断面図 
孔におけるすべり面深度は付近の孔内傾斜計から深さ $53 \mathrm{~m}$ に推定されている。間隙水圧計は移動土塊中に 3 箇 所の深度 (地表面より $43 \mathrm{~m}, 36 \mathrm{~m}, 27 \mathrm{~m}$ ) と不動基盤中 に 1 筒所（深度 $65 \mathrm{~m}$ ）の計 4 箇所に設置され，1日 4 回 6 時間間隔で観測を実施している。設置方法は谷の内地 すべりと同様である。

\section{3 . 降雨による地下水位上昇モデル ${ }^{5 / 6)}$}

一般に地下水位や間隙水圧 (以下地下水位等と称する) の変動は一年間を周期とする季節的な変動部分と日ごと の降雨による変動部分に分けられる。地すべり特性に よっては, 長周期変動を示さず，日ごとの降雨のみに呼 応して変動するものもある。ここでは, 降雨による地下 水位の上昇量, つまり日ごとの降雨による上昇量に焦点 を絞り，そのモデル化を検討した。

山地や丘陵地を構成する斜面に降雨として供給された 水は, 土塊に浸透して土塊内の不透水性地盤上にある地 下水面に達し, 地下水として流下する（図一-5）。一般に 地すべり地のある地点での水収支は，地すべりの上流流 域に与えられた降雨から蒸発散や地表流として損失され る量（無効降雨強度と称する）などを減じた值が，流出 量とその地点より上部斜面での貯留量の合計と一致する として表される7)。降雨による流出量の増加過程におい ては, 地すべり地での貯留量を無視するという仮定のも とで, 地すべり地内のある地点 $(\mathrm{P})$ における, 連続する 一様強度 $(\gamma)$ の降雨による流量増加量 $(\Delta Q)$ は, 無効 降雨強度 $(\alpha)$ を考慮すると, 定常状態で以下のように表 すことができる。

$$
\Delta Q=(\gamma-\alpha) \cdot A
$$

単位幅あたりの流量増加量は以下のとおりとなる。

$$
\Delta q=(\gamma-\alpha) \cdot \ell
$$

一方,

$$
\Delta q=\Delta h \cdot v \cdot \beta
$$

ダルシー則から

$$
v=k \cdot i
$$

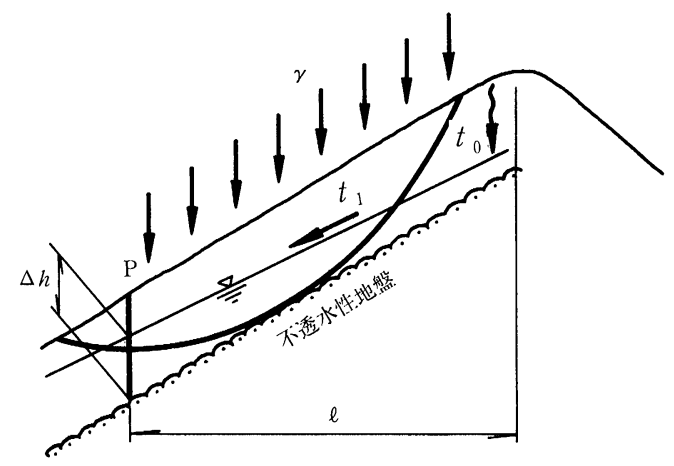

図ー5 モデル斜面

(1)，(2)，(3)式より

$$
\gamma=\frac{k \cdot i \cdot \beta}{\ell} \cdot \Delta h+\alpha
$$

$\Delta Q:$ 一様強度 $(\gamma)$ の降雨 による流量増加量 る一様降雨強度

$\alpha$ : 無効降雨強度

A: 点 $\mathrm{P}$ に地下水を供 給する区域（流域） の面積

$\Delta q$ : 単位幅当りの流量増 加量 $\gamma$ : 流域に与える連続す

$\ell:$ 流域の平均延長 $\Delta h$ : 点 $\mathrm{P}$ におる地下 水位上昇量

$v$ : 点 $\mathrm{P}$ におる地下 水流速

$\beta$ : 点 $\mathrm{P}$ におる土塊 の有効間隙率

$k$ : 点 $\mathrm{P}$ における透水 係数

$i$ : 点 $\mathrm{P}$ におる動水 勾配

$t r$ : 一様強度の降雨継続 時間

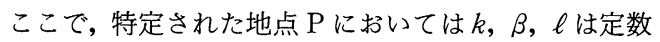
である。 $i$ は地下水位上昇過程において変化するが, その 変化量は小さく，ここでは一定と仮定する。

(4)式に用いた連続する一様強度の降雨による地下水位 の定常状態への移行は, 降雨の降り始めから降雨が地下 水面に達する時間 $\left(t_{0}\right)$, および区域 (流域) の最遠点地 下水面に到達した降雨が地下水となって地点 $\mathrm{P}$ に達す るまでの時間 $\left(t_{1}\right)$ との合計の時間の後である（図一 6)。また, (4)式に示す定常状態の地下水位は, $t r \geqq t_{1}$ の降 雨に対してのみ成立し, $t r<t_{1}$ の降雨に対しては, (4)式で 得られる水位上昇量より小さくなる。ここで, このモデ ルの特徴を以下に示す。

a ) 降雨強度と水位上昇量とには線形関係がある。

b ）この線形関係は $t_{1}$ 以上の降雨期間のあるものに対 して成立する。

c) 降雨強度が等しければ， $t_{1}$ 末満の降雨による水位 上昇量は $t_{1}$ 以上の降雨に比較して, 小さなものにな る。

d) 降雨強度が等しければ， $t_{1}$ の降雨による水位上昇 量と $t_{1}$ より長い降雨による上昇量とは等しくなる。 e ）地下水位の上昇量は, 素因である $k \cdot i \cdot \beta \cdot \ell \cdot$

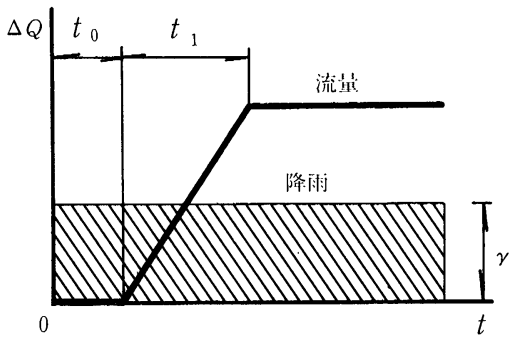

図６＼cjkstart流量の推移図 


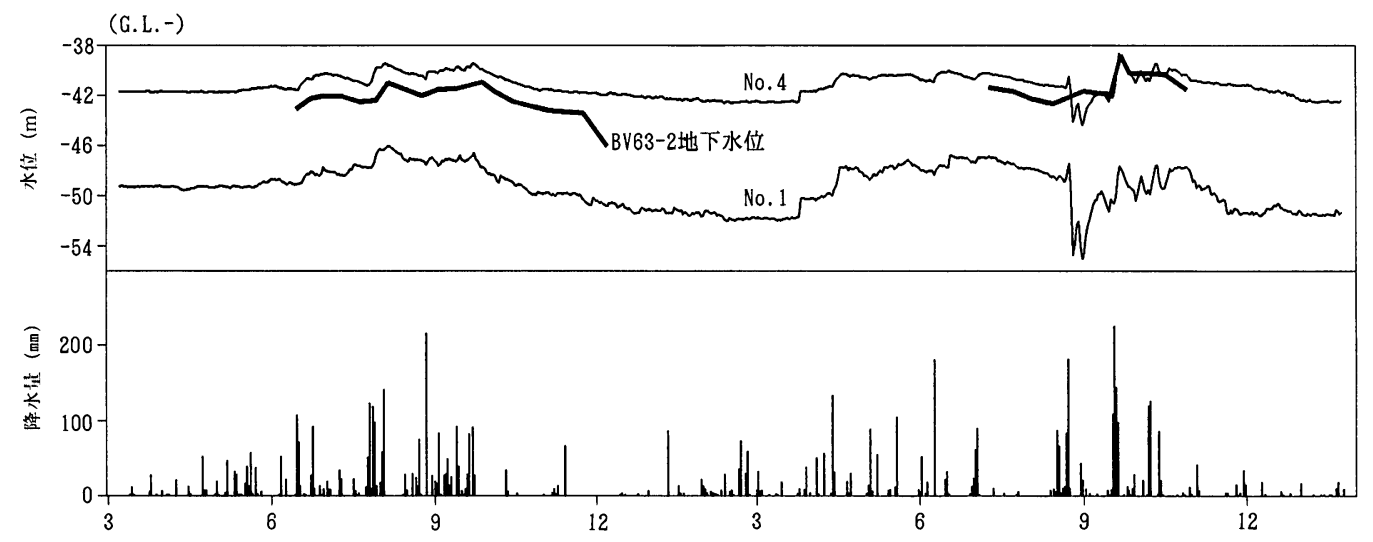

図-7 谷の内における降水量と換算地下水位, 地下水位の関係

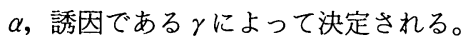

したがって，予め既存のデー夕から係数が同定されて いて, 降雨前の季節的な変動による地下水位の標高が明 らかになっていれば, このモデルにより, 日ごとの降雨 による地下水位が予測ができることになる。

このような関係が地下水位の上昇時において成立する と仮定し，このモデルを谷の内及び口坂本地すべりで観 測された間隙水圧を水位換算したデータに適用した。

\section{4. 地下水位上昇モデルを用いた解析結果}

\section{1 谷の内地すへりにおける解析結果}

\section{1 .1 水位上昇モデルによる解析}

平成元年 3 月から平成 2 年 12 月までに観測された間 隙水圧の状況を図 -7 に示す。この図から, 平成 2 年 8 月 25 日に間隙水圧計の值が急激に低下していることが分 かる。この現象の 12 日前から 2 日前までに連続雨轾 469 $\mathrm{mm}$, 最大日雨量 (8月 22 日) $206 \mathrm{~mm}$ を記録し, 伸縮計 にこの期間で $0.77 \mathrm{~mm}$ の累積傾向が見られ, さらに BV -61-2，61-3に設置されている綐型伸縮計に各々0.8 $\mathrm{mm}, 0.2 \mathrm{~mm}$ の変動が発生した。急激に低下した原因は 明確ではないが，すべり面での移動が新たな水みちを形 成し，水圧值が低下したことが考えられ，地すべりの運 動により間隙水圧の挙動が変化することを示している。 また，この時 BV-63-2 で週 1 回程度観測されている地 下水位は特に変化が生じていなかった。

解析は BV-63-2 孔のボーリングに設置されている間 隙水圧計 5 基のうち最下段のすべり面付近に設置されて いるもの（No. 1) を用いて実施した。また, 解析は図一 7 に示す観測期間の間隙水圧計（No. 1）のデータ及び高 知県越知土木事務所の時間雨基データを用い実施した。 降雨強度は 24 時間降雨強度を用い, 一連の連続降雨 $(24$ 時間以上の無降雨時間のない連続した降雨）をその降雨 日数で除して求めた。また, 換算地下水位の上昇量は,

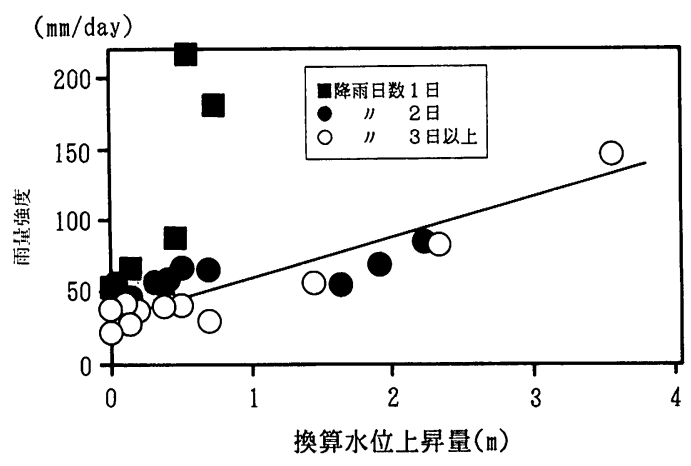

図-8 換算水位上舁量・雨量強度関係図（谷の内）

降雨状況と換算地下水位変動の関係から当該一連降雨に 呼応する換算地下水位の上昇量を特定して求め，降雨期 間中に換算地下水位の最大值が発生した場合は，それ以 前の降雨量により求めた。

解析結果を図 -8 に示す。この図から降雨日数 1 日間 （1～24 時間）のものは降雨強度に対する換算地下水位の 上昇量は小さいことが分かる。これはこのモデルのc） の特徵を表している。降雨日数 3 日間以上のものは, 降 雨強度と換算地下水位の上昇量とに相関があり, 今回の データから(5)式の関係が認められた（相関係数 0.949）。

$$
\gamma=0.0294 \cdot \Delta h+25.7
$$

$(\gamma: \mathrm{mm} / \mathrm{日}, \Delta h: \mathrm{mm})$

これは,このモデルのa）b）d）の特徴を表してい る。降雨日数 2 日間のものは前記両者の中間的な変動を 示している。なお，比較的上昇量の大きかった降雨日数 2 日間の三つのプロットは, 平成 2 年 8 月 25 日に間隙水 圧が急激に低下した直後のものである。地すべりの活動 により間啋水圧の応答特性に変化が発生することが推定 される。

(4)式の無効降雨強度（ $\alpha ）$ にあたるものが，(5)式では $25.7 \mathrm{~mm} /$ 日である。換算地下水位の上舁には, これ以上 
の降雨強度が必要であることを示している。また，この

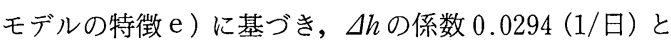
(4)式の第 1 項の係数 $(k \cdot i \cdot \beta / \ell)$ から, 透水係数が求め られる。ここで, 谷の内地すべりの流域延長を $\ell=970$ $\mathrm{m}$, 動水勾配（想定すべり面勾配）を $i=1 / 4.3$ とし, 有 効間隙率を $\beta=0.3$ と仮定して, 観測地点での地すべり 土塊の透水係数として $k=4.73 \times 10^{-1} \mathrm{~cm} / \mathrm{sec}$ が得られ た。

\section{1 .2 単位応答関数法による検討}

前述の解析結果によると降雨日数 3 日以上の降雨強度 と換算地下水位の上昇量には線形関係が見られた。観測 データを基に線型系のスペクトル解析 ${ }^{8)}$ を用いて，単位 降雨による換算地下水位の応答特性から, 近似的にこの 3 日の妥当性について検討した。実際の応答特性は素因 と誘因あるいは素因の時間的変化等が複雑に絡み合い, 降雨毎に異なっている。このためここでは，観測期間の データを同一の応答系として一度に解析することは避け た。降雨の集中する時期のデー夕から短期間の応答関係 を求めることは困難であったが，可能な限り短い期間内 で解析し個々の降雨に対する応答特性を求めた。また, 解析は(5)式の無効降雨強度 $(25.7 \mathrm{~mm} /$ 日) を観測された 降雨量から減じて実施した。解析結果を図ー 9 に示す。こ
の図から， $t_{0}$ の值は降雨によってかなりの差があること が分かる。このことは降雨毎に応答系が異なっているこ とを示す。しかし，上昇し始めてから最大值に近い值を 示すまでの期間 $\left(t_{1}\right)$ は $D$ を除いてすべて 3 日になってお り，このモデルの特徴 b ）にほほ合致していることが分 かる。

\section{2 口坂本地すべりにおける解析結果}

今回の解析は設置位置がすべり面に最も近い間隙水圧 計 (深度 $43 \mathrm{~m}$ ) の平成元年 6 月から 11 月までの観測結果 を用い実施した(図-10)。また, 降雨データは井川観測 所で観測された時間雨量を用いた。降雨強度は谷の内地 すべりと同様に 24 時間降雨強度を用いた。

\subsection{1 地下水位上昇モデルによる解析結果}

解析結果を図一11 に示す。この図から降雨日数 1.0 日 （1２4 時間）未満のものが最も降雨強度に対する換算地 下水位の上昇量が小さいことが分かる。これは，このモ デルのc）の特徵を表している。降雨日数 1.5 日以上の ものは換算地下水位の上昇量が大きく, 降雨強度と換算 地下水位の上昇量とは線形の相関関係があり, 今回の データから(6)式の関係が認められた（相関係数 0.842）。 これはこのモデルのa）b）d）の特徵を表している。 降雨日数 1.0 日以上 1.5 日未満のものは前記両者の中間
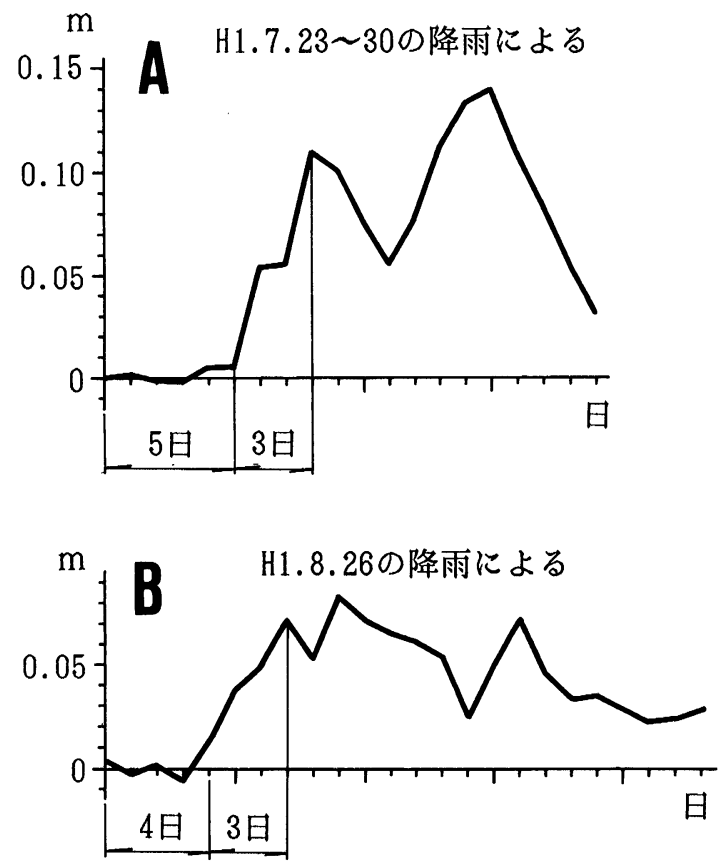
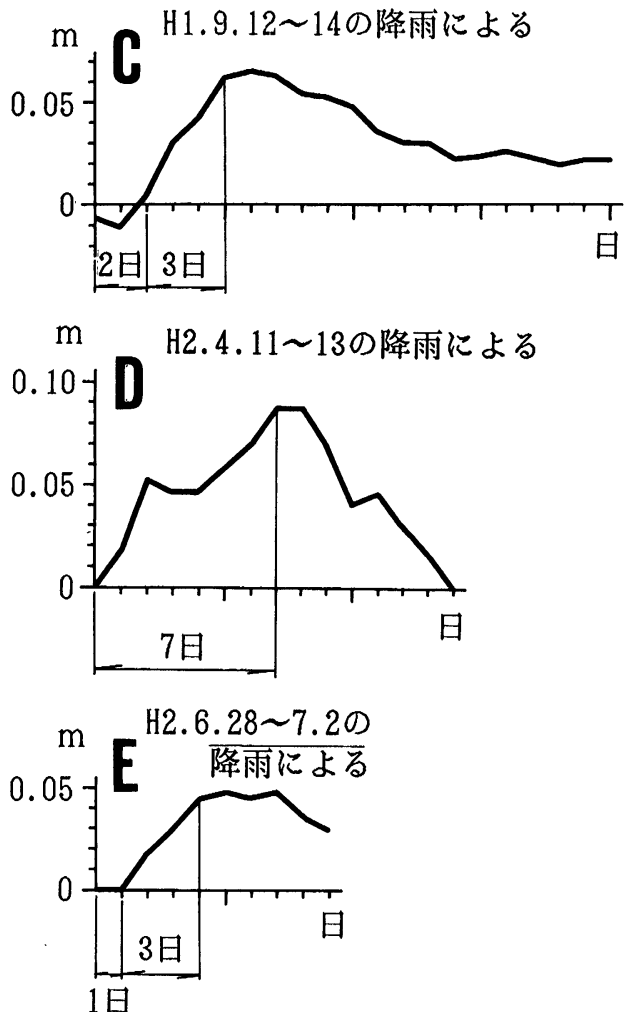

图－9 単位降雨による換算水位の水位（谷の内） 


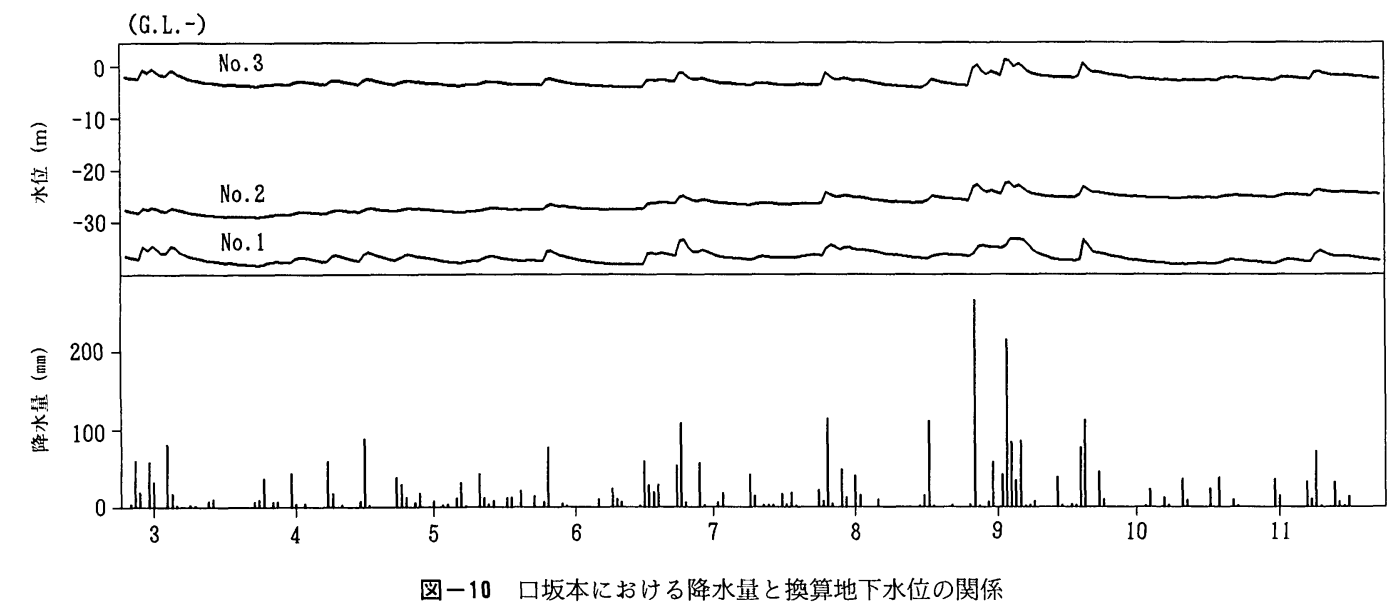

的な上昇量を示している。

$$
\gamma=0.0235 \cdot \Delta h+33.5
$$

( $\gamma: \mathrm{mm} /$ 日, $\Delta h: \mathrm{mm})$

この式から, 無効降雨強度 $(\alpha)$ は $33.5 \mathrm{~mm} /$ 日, $\Delta h$ の 係数は 0.0235 (1/日)であることが分かる。 $33.5 \mathrm{~mm} /$ 日 から, 口坂本地すべりは, 谷の内地すべりに比べ, 換算 地下水位の上昇をもたらすことのできる降雨強度として 若干大きな值が必要となる。一方, $\Delta h$ の係数 0.0235 (1/ 日）から, 単位降雨あたりの換算地下水位の上昇量は大 きいことが分かる。谷の内地すべりと同様, このモデル の特徵 e ）に基づき（4)式の第一項の係数を用い, 地す ベり地の流域延長を $\ell=410 \mathrm{~m}$, 動水勾配（すべり面勾 配）を $i=1 / 2.1$ とし, 有効間隙率を $\beta=0.3$ と仮定し て, 観測地点での地すべり土塊の透水係数として $k=$ $7.81 \times 10^{-2} \mathrm{~cm} / \mathrm{sec}$ が得られた。

降雨日数 1.5 日以上の降雨強度と換算地下水位の上昇 量とに相関があったことから，地下水位上昇モデルの $t_{1}$ が, 1.5 日程度であると推定される。そこで, 谷の内地す ベりと同様, 単位応答関数法により換算地下水位の応答 特性を上記の結果と比較検討した。

\section{2 .2 単位応答関数法による検討}

谷の内地すべりと同様の手順で解析を実施した。また, (6)式の無効降雨強度 $(33.5 \mathrm{~mm} /$ 日) を観測された降雨量 から減じた。解析結果を図ー12 に示す。この図から，口

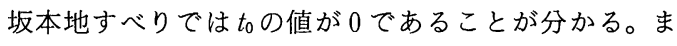
た，上昇から最大值に近い值を示すまでの期間 $\left(t_{1}\right)$ は $\mathrm{A}, \mathrm{B}, \mathrm{D}$ が 1 日, C, E, F が 2 日になっており，地下水 上昇モデルによる解析結果の 1.5 日にほほ合致している ことから，このモデルの特徵b）に整合していることが 分かる。

\section{5. 結 語}

本論文により得られた結論は以下のとおりである。

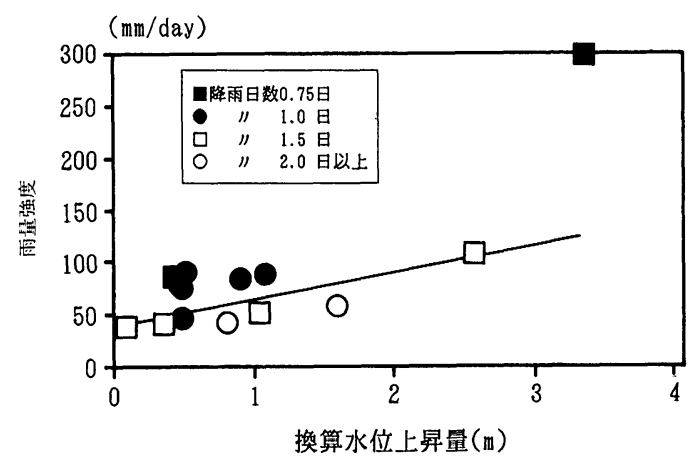

図-11 換算水位上舁量・雨量強度関係図（口坂本）

（1）河川流出解析にしばしば用いられている合理式の 考え方を基本にし，地下水位の季節的な変動などの基 底值が明かな場合に， $t_{1}$ より長い降雨に対する地下水 位の予測ができる水位上昇モデルを提案した。

（2）このモデルの妥当性を検討するため，高知県の谷 の内地すべりと静岡県の口坂本地すべりを対象に解析 を実施し, その結果, モデルの特徴 a ) 〜 e ) を確認 できた。

（3）既往のデータからこのモデルが同定できれば, 地 すべりの降雨による地下水位の挙動特性を明らかにす ることができる。

（4）このモデル及び解析例から， $t_{1}$ の長さの違いによ り，地下水位等に影響をもたらす降雨特性に違いがあ ることが分かる。

しかし, 降雨による地下水位等の挙動は, ここで焦点 を絞った降雨と地下水位の応答の遅れ時間 $\left(t_{1}\right)$ 以外に, 素因に係わるものとして, 地すべり地からの蒸発散や地 表流としての損失, 不飽和带及び飽和带における地下水 の挙動など, 多くの要因が複雑に関連する現象である。 今回の解析モデルでは土層の漫透能の変化については考 虑されていない。従ってこの点について研究を進める必 

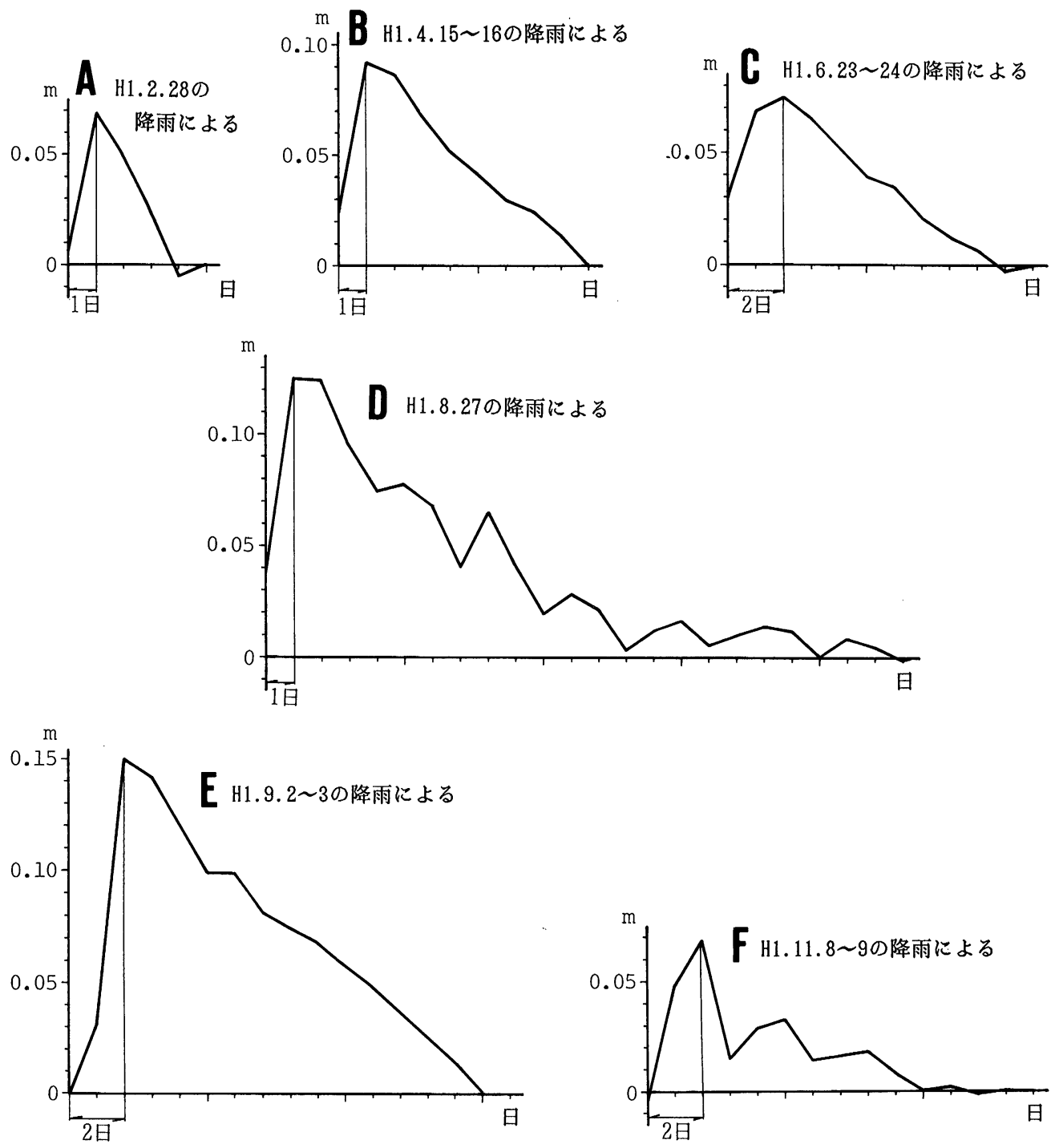

図一12 単位降雨による換算地下水位の水位（口坂本）

要があると考える。

最後に, 単位応答関数法による解析に協力頂いた地す ベり研究室の石濱茂氏に感謝の意を表する次第である。

\section{参考文献}

1) 渡 正亮，小橋澄治 1987: 地すべり・斜面崩壊の予知と 対策, 山海堂, pp. 54〜 56, pp. 97-104

2 ) 檜垣大助, 丸山清輝, 吉田克美, 吉松弘行 1991: 地す心゙ り地における間隙水圧変動の観測, 地すべり Vol. 28, No. 3 , pp. $9-16$

3 ) 鍋島哲彦, 藤原一司, 水落克則, 上野郁夫, 吉村典宏 1989: 高知県の地すべり一砂防課（建設省）における地すべり 対策について一，地すべり技術 $15-3$, pp. 4-18
4 ）中村浩之, 綱木亮介, 吉田克美 1990: 静岡県口坂本地す ベり災害現地調查報告書, 土木研究所資料第 2857 号, pp. 3

5 ) 吉松弘行, 近藤観慈, 吉田克美 1991: モデル試験地にお ける降雨による間吵水圧の変動, 第 30 回地すべり学会研 究発表講演集, pp. 235-238

6 ) 吉松弘行, 近藤観慈, 吉田克美 1991: 地すべり地におけ る水収支一谷の内地すべりを対象にしてー, 地すべり学 会関西支部現地討論会, pp. 17-31

7 ) 大滝俊夫 1965: 降雨によるがけくずれの水文学的研究, 研究時報第 17 巻 6 号, pp. $1-45$

8 ）日野幹雄 1977: スペクトル解析, 朝倉書店

（原稿受理日 平成 4 年 4 月 8 日） 
千葉県嶺丘隆起帯縁辺部の粘質土地すべりの発生機構と対策

「地すべり」Vol. 29, No. 2（通算第 110 号）pp. 1〜11，1992 年（平成 4 年）9月

守随 治雄

長者地すべり地における地すべり斜面の変遷過程

「地すべり」Vol. 29, No. 2（通算第 110 号）pp. 12 19, 1992 年（平成 4 年）9 月

檜垣 大助

高知県長者地すべり地において，地質ボーリング資料から地すべり斜面の変遷過程を考察した。

当地すべり地は少なくとも 1,000 年以上前からの順次移動ブロックを拡大する後退性地すべりとして形成され

てきた。現在の地すべりの活動も過去の地すべり斜面変遷過程とよく調和している。

降雨, 地下水変動による土地電位の挙動

「地すべり」Vol. 29, No. 2（通算第 110 号）pp. 20〜27, 1992 年（平成 4 年）9月

伊藤 芳朗, 南雲 政博

新潟県平丸の地すべり観測システムにおいて, 観測された土地電位の変化について, 次の 3 タイプについて詳 述した。(1)降雨によって発生する中間流に伴う流動電位, 降雨電位効果。(2)地下水流動による流動電位, 地下水 電位効果。(3)断続降雨と地下水位変動に伴う流動電位, 複合電位効果。土地電位の連続観測は, 降雨による表面 流出，中間流，漫透，地下水涵養，地下水流動などの考察に，有力な情報を提供することを示した。

地すべり地における水位変動のモデル解析

「地すべり」Vol. 29, No. 2（通算第 110 号）pp. 28〜38, 1992 年（平成 4 年）9月

榎田 充哉

地すべり滑動にすべり面の間隙水圧が関与していることは周知の事実であるが，本研究では地すべり地の水位 変動をモデル化し，モデル化することの意義とモデルの有効性について検討を行った。

破砕帯地すべりにおける地下水位の挙動特性

「地すべり」Vol. 29, No. 2 (通算第 110 号) pp. 39〜45, 1992 年（平成 4 年） 9 月

近藤 観慈, 吉松 弘行, 吉田 克美

河川流出解析にしばしば用いられる合理式の考え方を基本にし，地下水位の季節的な変動值が明かな場合に， 降雨による地下水位変化が予測できる地下水位上昇モデルを検討した。このモデルの妥当性を検討するため, 谷 の内地すべりと口坂本地すべりを対象に解析を実施し，このモデルの特徴を確認した。このモデルが既往のデー 夕から同定できれば，降雨による地すべりの地下水位等の挙動特性を明らかにすることができることを示した。 